\title{
Coeliac disease presenting as acute bleeding disorders
}

\author{
DAVID R. GRAHAM \\ M.B., M.R.C.P. \\ Alistair J. Bellingham \\ F.R.C.P.
}

Department of Haematology, Royal Liverpool Hospital, Liverpool L7 8XP

\author{
ELSPETh Alstead \\ M.B., M.R.C.P.
}
NeVILLE KRASNER
M.D., F.R.C.P.

\author{
JOHN MARTINDALE \\ M.B., Ch.B., F.R.C.Path. \\ Department of Gastroenterology, Walton Hospital, Liverpool L9 IAE
}

\begin{abstract}
Summary
Two young women presented with acute bleeding disorders and were subsequently found to have coeliac disease.

\section{Introduction}

The presentation of coeliac disease as an acute bleeding disorder is an unusual event. Two recent cases are reported in which the bleeding disorder was of such severity that the patients presented as emergencies to haematologists.
\end{abstract}

\section{Case 1}

A previously well, 27-year-old woman was admitted to an acute haematology unit with multiple severe bruising. For 3 months before admission she had been having vague colicky abdominal pain with pale, bulky, offensive stools which were difficult to flush away. She had lost $9.5 \mathrm{~kg}$ in weight. Two weeks before admission she had developed spontaneous bruising of her limbs. She had no melaena or haematuria. She was unemployed, a non-smoker, and she drank three pints of beer nightly. She had a normal diet and was on no drugs.

Examination showed her to be pale with multiple old and fresh bruises as well as large haematomas on her legs. There were no cutaneous stigmata of liver disease. The abdomen was slightly distended and rectal examination showed pale stools only. Examination was otherwise normal.

Investigations showed $\mathrm{Hb} 9.5 \mathrm{~g} / \mathrm{dl}$; WCC $7.6 \times$ $10^{9} / 1$; platelets $510 \times 10^{9} / 1 ; \quad \mathrm{MCV} 90 \mathrm{fl} ; \mathrm{MCH}$ $30.3 \mathrm{pg}$; MCHC $32.0 \mathrm{~g} / \mathrm{dl}$; reticulocytes $5 \%$; iron $6 \mu \mathrm{mol} / 1$; (normal 10-30), serum albumin $25 \mathrm{~g} / 1$; calcium 2.3 mmol/1; (normal 2.18-2.62); $\mathrm{B}_{12} 320$ $\mathrm{ng} / \mathrm{l}$ (normal >260); folate $1.7 \mu \mathrm{g} / \mathrm{l}$ (normal $>3$ ); prothrombin time $120 \mathrm{sec}$ (control 12); kaolin- cephalin clotting time (KCCT) $120 \mathrm{~s}$ (control 42). Clotting factors II, VII and X were all present in reduced concentration. Sigmoidoscopy was normal. Barium follow-through findings showed disease of the jejunum with a malabsorptive pattern.

The patient was treated with fresh frozen plasma and vitamin $K$ intravenously and oral iron an folate supplements. Her prothrombin time returne to normal immediately and she showed a goos reticulocyte response. She was allowed home $\mathrm{e}^{+}$ awaiting a jejunal biopsy as an out-patient. However, soon after discharge she was admitted with tetany due to hypocalaemia, and was treated with intravenous calcium. A jejunal biopsy was performed, which showed sub-total villous atrophy, strongly in favour of coeliac disease. She was started on a gluten-free diet and was well some three months later with a normal bowel habit and haematological indices. Repeat biopsy was arranged but the patient has since left the area.

\section{Case 2}

A 21-year-old Jehovah's Witness was admitted with a 3-day history of spontaneous bruising and bleeding per rectum. On closer questioning she admitted to occasional diarrhoea and stools which were loose and offensive. She had lost $12.7 \mathrm{~kg}$ in weight and had developed amenorrhoea, despite a good appetite over the previous year.

Examination showed her to be pale and thin, with multiple bruises on her arms and legs. She had a large haematoma of her right foot and a haemarthrosis of her right knee. The abdomen was distended and slightly tender.

Investigations showed her $\mathrm{Hb}$ to be $9.6 \mathrm{~g} / 1$ which fell to $3.9 \mathrm{~g} / 1$ on the second day; WCC $13.2 \times 10^{9} / 1$; prothrombin time was $180 \mathrm{~s}$; KCCT $180 \mathrm{~s}$; plasma 
fibrinogen $2 \cdot 59 \mathrm{~g} / 1$ (normal 2·0-4.0). Fibrinogen degradation products $6 \mu \mathrm{g} / \mathrm{ml}$; factor II $1 \%$, factor VII $5 \%$, factor X $4 \cdot 1 \%, \mathrm{Na}^{+} 131 \mathrm{mmol} / 1, \mathrm{~K}^{+} 2 \cdot 3$ $\mathrm{mmol} / \mathrm{l}$, serum calcium $1.51 \mathrm{mmol} / \mathrm{l}$, phosphate $0.72 \mathrm{mmol} / 1$; alkaline phosphatase $2.7 \mathrm{~K}$.A. units; albumin $23 \mathrm{~g} / 1$.

Vitamin $\mathrm{K}$ was given with reversion of the clotting screen to normal within 24 hours. The patient, however, refused blood transfusion on religious grounds and was therefore given parenteral haematinicsiron, $B_{12}$ and folate together with parenteral nutrition.

A provisional diagnosis of coeliac disease was made on the basis of the history of vitamin $\mathrm{K}$ deficiency, hypoproteinaemia, anaemia and biochemical osteomalacia. Xylose absorption was impaired and faecal fat excretion was raised. Jejunal biopsy was performed and confirmed the presence of sub-total villous atrophy. A barium meal and follow-through examination showed no specific abnormalities.

She was allowed home on a gluten-free diet and was well some nine months later when jejunal biopsy was repeated and histology showed an improvement to partial villous atrophy. Her menstruation had returned to normal.

\section{Discussion}

Both patients who had been previously well, presented not with gastrointestinal symptoms, but dramatically in the manner described and were thought initially to have a blood dyscrasia. Review of several large series shows that although the occur- rence of hypoprothrombinaemia is common, prolonged prothrombin times being found in up to $70 \%$ of untreated adult cases, (Green and Wollaeger, 1960; Bosak, Wang and Aldersberg, 1957; Barry, Baker and Read, 1974; Benson, Kowlessar and Schleisenger, 1964; Ross and Gibb, 1966), overt and severe bleeding only rarely has been reported as the initial presenting feature (Benson et al., 1964).

Although hepatic dysfunction, either due to disease or anticoagulant therapy, is the commonest cause of an acute bleeding disorder with a prolonged prothrombin time, the authors wish to emphasize that it may be the primary presenting feature in coeliac disease due to malabsorption of vitamin $\mathrm{K}$.

\section{Acknowledgments}

We would like to thank Dr F. Crowley for referring case 1 and Dr R. Ferguson for performing the jejunal biopsy.

\section{References}

BARRY, R.E., BAKer, P. \& ReAD, A.E. (1974) The clinical presentation of celiac disease. Clinics in Gastroenterology, $3,1$.

Benson, G.D., Kowlessar, O.B. \& Schleisenger, A.H. (1964) Adult celiac disease with emphasis on the response to gluten-free diet. Medicine (Baltimore), 43, 1.

Bosak, E.T., Wang, G. \& Aldersberg, D. (1957) Clinical aspects of the malabsorption syndrome. In: The Malabsorption Syndrome (Ed by Aldersberg, D.), p. 112. Grune \& Stratton, New York.

Green, P.A. \& Wollaeger, E.E. (1960) Clinical behaviour of sprue in the United States. Gastroenterology, 38, 399.

Ross, J.R. \& GIBB, S.P. (1966) Systemic manifestations of Gluten Enteropathy. Medical Clinics of North America, 50, 515. 